\title{
PENGEMBANGAN LKS BERBASIS INKUIRI TERBIMBING UNTUK MEMBERDAYAKAN LITERASI LINGKUNGAN SISWA KELAS V SDN 5 BABADAN KECAMATAN NGAJUM
}

\author{
Diana Kusumaningrum ${ }^{1}$, Yuli lka Tanti ${ }^{2}$ \\ ${ }^{1}$ Universitas Islam Raden Rahmat Malang \\ Email: kusumadiana856@gmail.com \\ ${ }^{2}$ Universitas Islam Raden Rahmat Malang \\ Email: yuliikatanti@gmail.com
}

\begin{abstract}
Abstrak
Penelitian ini bertujuan untuk mengetahui tingkat kevalidan, keterbacaan, serta ingin mengetahui apakah LKS berbasis inkuiri terbimbing dapat memberdayakan literasi lingkungan siswa. Penelitian ini merupakan penelitian Research and Development (R\&D). Model yang digunakan adalah model Borg \& Gall. Subjek penelitian adalah siswa kelas V SDN Babadan 5 Kecamatan Ngajum Kabupaten Malang tahun pembelajaran 2019/2020 yang tediri dari 20 siswa. Dalam penelitian ini materi pokok yang digunakan adalah pada mata pelajaran IPA siklus air. Instrumen yang digunakan antara lain soal tes, RPP, angket keterlaksanaan tindakan guru da siswa, respon siswa, validasi RPP, validasi LKS, validasi soal tes, dan penilaian kegiatan motorik siswa. Data yang dihasilkan berupa validasi produk LKS, soal tes, dan RPP, hasil pretest dan postest, respon siswa, self assesment dan peer assesment, dan hasil penilaian kegiatan motorik siswa. Berdasarkan hasil penelitian menunjukkan bahwa kualitas LKS berbasis inkuiri terbimbing untuk memberdayakan literasi lingkungan siswa dapat ditinjau dari aspek kelayakan secara keseluruhan baik dan sangat layak digunakan dalam pembelajaran serta LKS ini dapat memberdayakan literasi lingkungan siswa.
\end{abstract}

Kata kunci: LKS Berbasis Inkuiri Terbimbing, Literasi Lingkungan

\begin{abstract}
This study aims to see the level of validity, readability, and to see whether guided inquiry-based worksheets can be read by students. This research is a research and development (R\&D). The model used is the Borg \& Gall model. The research subjects were fifth grade students of SDN Babadan 5, Ngajum District, Malang Regency, the 2019/2020 learning year, which consisted of 20 students. In this study, the main material used is the air cycle science subject. The instruments used include test questions, lesson plans, teacher and student action implementation, student responsibility, lesson plan validation, student worksheet validation, test question validation, and student motor activity assessment. The resulting data were in the form of validation of student worksheets, test questions and lesson plans, pretest and posttest results, student responses, selfassessment and peer assessment, and student motor activity results. Based on the results of the study, it shows that the quality of guided inquiry-based worksheets to empower students 'environmental literacy can be viewed from the total feasibility aspect and is very suitable for use in learning and this worksheets can empower students' environmental literacy.
\end{abstract}

Keywords: Worksheet Based on Guided Inquiry, with Environmental Literacy 


\section{Pendahuluan}

Kurikulum 2013 dikembangkan dengan tujuan agar berkembangnya potensi peserta didik menjadi manusia yang beriman, dan berguna bagi nusa dan bangsa. Peserta didik harus dibimbing untuk mengenal potensinya sejak dini dan mampu mengembangkannya dengan bantuan guru agar memiliki pandangan yang luas untuk mencapai suatu cita-cita yang diharapkan dan mampu beradaptasi dalam berbagai lingkungan. Salah satu cara yang dapat dilakukan untuk memperbaiki kualitas pembelajaran adalah dengan menggunakan bahan ajar yang mampu membuat peserta didik aktif, mampu memecahkan masalah di dalam kehidupannya dengan menggunakan konsep pengetahuan yang telah dipelajari. Peserta didik juga akan didorong untuk belajar memaknai apa yang dipelajarinya, salah satunya adalah dengan mengembangkan bahan ajar lembar kerja siswa (LKS) berbasis inkuiri terbimbing.

(Prastowo, 2019) menyatakan bahwa LKS merupakan materi ajar yang sudah dikemas sedemikian rupa sehingga siswa diharapkan dapat mempelajari materi ajar tersebut secara mandiri. Berdasarkan penjelasan tersebut dapat disimpulkan bahwa LKS merupakan suatu bahan ajar cetak yang berupa lembar-lembar kertas yang berisi materi ringkasan dan petunjuk pelaksanaan tugas pembelajaran yang harus dikerjakan siswa, baik bersifat teoritis atau praktis yang mengacu pada kompetensi dasar yang harus dicapai siswa. Lembar Kerja Siswa (LKS) yang menggunakan pembelajaran inkuiri terbimbing akan lebih efektif dan lebih terarah jika peserta didik dalam pembelajaran melakukan suatu percobaan melalui praktek di lapangan dan dapat meningkatkan pemahaman untuk mengaplikasikan ilmu salah satunya adalah pengetahuan literasi lingkungan.

(Kusumaningrum \& Muslihasari 2019) menyatakan bahwa literasi lingkungan merupakan kemampuan individu untuk memahami dan menafsirkan keadaan lingkungan. Penanaman literasi lingkungan pada peserta didik perlu dikembangan dalam pembelajaran yang sesuai kebutuhan dan minat setiap anak serta mampu memanfaatkan rasa ingin tahu anak untuk mengenal dunia sekitarnya. Oleh sebab itu, sekolah harus memberikan praktek pembelajaran yang efektif untuk mengembangkan perilaku bertanggung jawab terhadap lingkungan. Selain itu, kegiatan belajar harus memberikan kesempatan untuk belajar di luar kelas, mengamati alam, berlatih dan menguji isu-isu belajar tentang lingkungan guna memberdayakan kemampuan literasi lingkungan pada siswa.

Peningkatan literasi lingkungan kepada peserta didik dapat dilakukan dengan berbagai cara dalam proses pembelajaran. Beberapa penelitian terkait literasi lingkungan diantaranya penelitian tentang pengembangan bahan ajar perubahan lingkungan berbasis realitasi lokal dan literasi lingkungan telah dilakukan Sriyati \& Mukhayati (2015) dan menunjukkan bahwa hasil uji keterbacaan bahan ajar yang dikembangkan memiliki kategori tinggi. Demikian juga Tumisem (2007) dalam penelitiannya menemukan bahwa pelaksnaan program pendidikan 
lingkungan berbasis ekologi perairan melalui kegiatan pramuka di SD dapat meningkatkan literasi lingkungan sebesar $47 \%$ dan mengubah sikap siswa terhadap lingkungan perairan sebesar 52\%. (Amini, 2010) dalam penelitiannya menemukan bahwa model pembelajaran pendidikan lingkungan berbasis outdoor pada calon guru sekolah dasar (SD) dapat meningkatkan penguasaan konsep, kinerja dan sikap dalam melakukan percobaan, kemampuan dalam pembelajaran, sikap dan perilaku peduli terhadap lingkungan sekolah.

Berdasarkan dari hasil observasi hari Kamis pada tanggal 07 November 2019. Penerapan literasi lingkungan di SDN 5 Babadan tergolong masih kurang maksimal. Hal ini bisa dilihat dari sikap dan perilaku peserta didik akan kebersihan lingkungan, di sekolah masih terdapat sampah-sampah yang berserakan, halaman sekolah yang masih terlihat kotor, dan terdapat tanaman bunga yang rusak kering karena diinjak dan belum disiram. Hal ini membuktikan bahwa sikap dan perilaku peserta didik tentang literasi lingkungan sangat kurang. Peserta didik juga tidak pernah melakukan pembelajaran di luar kelas seperti melakukan percobaanpercobaan, pengamatan, yang dapat melatih dan mengembangkan kemampuan berpikirnya terhadap literasi lingkungan.

Berdasarkan fakta yang ditemukan peneliti saat melakukan wawancara kepada guru kelas V SDN 5 Babadan kendala yang dialami adalah kurangnya peduli siswa terhadap kebersihan, dan ada beberapa peserta didik yang mengalami kesulitan dalam belajar, mudah bosan saat di dalam kelas, dan proses pembelajaran guru hanya difasilitasi dengan buku LKS tema, dimana peserta didik hanya mengerjakan soal-soal yang sudah tersedia di dalam LKS tersebut. Hal ini juga didapatkan melalui wawancara dengan tiga peserta didik kelas $\mathrm{V}$ menyatakan bahwa tidak pernah diadakannya kegiatan-kegiatan pembelajaran secara praktikum.

Di sisi lain pembelajaran yang dilaksanakan di dalam kelas masih menggunakan media yang sederhana dalam menyampaikan meteri pelajaran. LKS yang digunakan dalam pembelajaran hanya berisi materi dan latihan soal yang belum membangun konsep siswa. Oleh karena itu peneliti ingin membuat bahan ajar yang dapat membantu peserta didik untuk memberdayakan keterampilan literasi lingkungan, bahan ajar tersebut adalah LKS berbasis inkuiri terbimbing untuk memberdayakan ketrampilan literasi lingkungan siswa. Ketrampilan literasi lingkungan atau disebut juga dengan sikap dan perilaku sadar akan lingkungan adalah tanggung jawab setiap peserta didik, yang pada umumnya sangat dipengaruhi oleh tingkat pengetahuan yang mereka miliki. Jika tingkat pengetahuan yang mereka miliki tinggi maka akan berpengaruh pada sikap dan perilaku terhadap lingkungan juga akan baik.

Salah satu untuk meningkatkan pengetahuan ketrampilan literasi lingkungan yaitu penggunaan bahan ajar LKS berbasis inkuiri terbimbing. Yang diharapkan dapat memberikan motivasi dan semangat peserta didik dalam pembelajaran, serta memberikan kemudahan peserta didik dalam menyerap informasi dan pengetahuan 
dengan baik. Bahan ajar dalam pembelajaran memiliki kedudukan sangat penting dan memberikan pengaruh besar dalam proses pembelajaran, diantaranya untuk menciptakan suasana pembelajaran yang aktif, kreatif, inovatif, efektif, dan menyenangkan. Guru dituntut untuk menciptakan proses pembelajaran yang dapat membangkitkan minat belajar peserta didik. Peneliti ingin mengembangakan bahan ajar dalam pembelajaran tematik dengan judul "Pengembangan Lembar Kerja Siswa (LKS) Berbasis Inkuiri Terbimbing Untuk Memberdayakan Ketrampilan Literasi Lingkungan Siswa Di SDN 5 Babadan Kecamatan Ngajum "

\section{Metode Penelitian}

Penelitian ini dilakukan dengan menggunakan pendekatan Penelitian Pengembangan (Research and Development). Menurut Borg and Gall (Sugiyono, 2010) yang dimaksud dengan model penelitian dan pengembangan adalah penelitian yang digunakan untuk menghasilkan produk tertentu untuk menguji keefektifan produk yang dibuat.

Pada penelitian ini, langkah pengembangan LKS ini akan disederhanakan dan dibatasi hanya dengan dihasilkannya produk setelah revisi uji coba skala luas. Penelitian ini bertujuan untuk mengembangkan produk berupa LKS Berbasis Inkuiri Terbimbing Untuk Memberdayakan Literasi Lingkungan yang akan digunakan sebagai media belajar.

Prosedur ini menggunakan model pengembangan yang dikembangkan oleh Borg and Gall. Dalam Sugiyono,
(2010) pendekatan Research and Development ( $R$ \& $D)$ dalam pendidikan meliputi sepuluh langkah yaitu: 1) potensi masalah, 2) pengumpulan data, 3) desain produk, 4) validasi desain, 5) revisi desain, 6) uji coba produk, 7) revisi produk, 8) uji coba pemakaian, 9) revisi produk, dan 10) produksi masal.

Berdasarkan

Langkah-langkah tersebut, peneliti membatasi hanya tujuh langkah dari sepuluh langkah tersebut yaitu diantaranya: 1) potensi dan masalah, 2) pengumpulan data, 3) desain produk, 4) validasi desain, 5) revisi desain, 6) uji coba produk, 7) dan revisi produk.

Subjek penelitian adalah kelas $\mathrm{V}$ SDN 5 Babadan dengan jumlah 20 siswa, terdiri dari 9 siswa laki-laki dan 11 siswa perempuan. Uji coba pada penelitian ini dilakukan menjadi dua tahap yaitu uji coba kelompok kecil yang dilakukan oeh 6 siswa dan uji coba kelompok besar yang dilakukan 20 siswa. Berdasarkan observasi yang peneliti lakukan dalam proses pembelajaran di kelas adalah kurangnya motivasi belajar peserta didik di kelas sehingga berpengaruh terhadap hasil belajar yang dicapai kurang maksimal, dan kesadaran peserta didik dalam kebersihan lingkungan sekitar sekolah juga masih kurang dan belum adanya pembelajaran tentang literasi lingkungan. LKS yang digunakan dalam pembelajaran hanya berisi latihan soal yang belum membangun konsep siswa.

Teknik penelitian yang digunakan untuk mengumpulkan data dalam uji coba yaitu: observasi, dokumentasi, wawancara, tes hasil belajar, dan angket. Instrumen penelitian yang digunakan untuk mengumpulkan data 
dalam uji coba, yaitu: Lembar angket yang meliputi: soal tes, Rencana Pelaksanaan Pembelajaran (RPP), angket keterlaksanaan tindakan guru dan aktivitas siswa, dan angket respon siswa.

\section{A. Teknik Analisis data}

\section{Validasi Produk}

a. Produk LKS

Dalam kualitas LKS yang diperoleh dari pengisian lembar penilaian oleh validator ahli media dimuat dalam bentuk tabel kelayakan produk dan saran kemudian data dijadikan landasan untuk melakukan revisi setiap komponen dari LKS yang dikembangkan. Metode analisis data yang digunakan dalam penelitian ini dianalisis dengan metode deskriptif kualitatif. Analisis validitas LKS terdiri data skor hasil validasi LKS digunakan untuk mengetahui kelayakan LKS secara teoritis ditinjau dari setiap aspek. Skor penjabaran kriteria pada masing-masing aspek berdasarkan Tabel 1 skala linkert di bawah ini:

\section{Tabel 1 Skor Skala Linkert Kelayakan LKS}

\begin{tabular}{ll}
\hline Penilaian & Skala \\
\hline Kurang baik & 1 \\
\hline Cukup baik & 2 \\
\hline Baik & 3 \\
\hline Sangat baik & 4
\end{tabular}

(Adaptasi Depdiknas, 2008)

Penilaian hasil validasi LKS untuk setiap aspek dengan cara mencari skor rata - rata pada setiap aspek:

$$
\text { Skor rata-rata }=\frac{\text { Skor yamg didapat }}{\text { Skor Maksimal }}
$$

(Depdiknas, 2008)

Selanjutnya setiap skor dianalisis dengan kriteria intepretasi skor Penskoran pada analisis data instrumen validasi dapat dilihat pada Tabel 2 di bawah ini.

Tabel 2 Kategori Hasil Pengukuran LKS

\begin{tabular}{cl}
\hline Skor rata-rata (\%) & kategori \\
\hline $21-40$ & Kurang layak \\
\hline $41-60$ & Cukup layak \\
\hline $61-80$ & Layak \\
\hline $81-100$ & Sangat layak
\end{tabular}

(Adaptasi Depdiknas, 2008)

Selanjutnya persentase ketuntasan untuk setiap aspek dianalisis dengan menggunakan rumus:

Persentase ketuntasan secara keseluruhan $=$ $\frac{\Sigma \text { Skor rata-rata yamg Diperoleh }}{\Sigma S k o r ~} \times 100 \%$ ¿Skor keseluruhan

(Depdiknas, 2008)

\section{b. Validasi Soal Tes}

(Arikunto, 2010) menyatakan bahwa suatu tes dilakukan valid apabila tes tersebut mengukur apa yang hendak diukur. Valid berarti sahih, artinya keabsahan tes tersebut sudah tidak diragukan lagi. Hasil penelitian yang

77 | Pengembangan LKS Berbasis Inkuiri Terbimbing untuk memberdayakan Literasi 
telah diberikan disebut data hasil validasi yang kemudian dimuat dalam tabel hasil validasi. Rumus persentase yang di gunakan adalah sebagai berikut:
Kriteria kelayakan dapat dilihat pada Tabel 3 di bawah ini:

Skor Akhir $=\frac{\text { Skor yamg Diperoleh }}{\text { Skor tertinggi }} \times 100 \%$

(Mahmudah, 2019)

Tabel 3 Kriteria Kelayakan Soal Tes

\begin{tabular}{ll}
\hline Kriteria Validasi & Tingkat Validitas \\
\hline $81,0 \%-100 \%$ & Sangat Valid, dapat digunakan tanpa revisi \\
\hline $61,0 \%-80,9 \%$ & Valid, dapat digunakan namun perlu revisi \\
\hline $41,0 \%-60,9 \%$ & $\begin{array}{c}\text { Cukup valid, disarankan tidak digunakan karena } \\
\text { perlu revisi besar }\end{array}$ \\
\hline $21,0 \%-40,9 \%$ & Kurang valid, tidak boleh dipergunakan \\
\hline $21,0 \%$ & Tidak valid, tidak boleh dipergunakan \\
\hline
\end{tabular}

(Adaptasi Mahmudah, 2011)

\section{Validasi RPP}

Pada analisis data hasil validasi RPP dilakukan dengan mencari rat-rata setiap komponen dalam validasi dan rata-rata dari semua komponen dalam validasi RPP, sehingga mendapatkan rata-rata total penilaian validator terhadap kevalidan RPP. Mencari rata-rata setiap komponen menggunakan rumus:

$$
P_{1}=\frac{N}{b}
$$

Keterangan:

$P_{1}=$ rata-rata komponen ke-1

$N=$ total skor

$b$ = banyak indikator dalam setiap komponen (Waluyo, 2017: 33)
Sedangkan untuk mencari rata-rata total validasi (RTV) digunakan rumus:

$$
R T V=\frac{\Sigma P}{k}
$$

Keterangan:

$R T V \quad=$ Rata-rata total validitas

$\Sigma P=\Sigma$ rata-rata setiap komponen

$k=$ jumlah komonen (Waluyo, 2017: 33)

Berikut dapat dilihat pada Tabel 4 kategori kevalidan rencana pelaksanaan pembelajaran (RPP). 
Tabel 4 Kategori Kevalidan RPP

\begin{tabular}{ll}
\hline Interval skor & Kategori \\
\hline$R T V=4$ & Sangat valid \\
\hline $3 \leq R T V<4$ & Valid \\
\hline $2 \leq R T V<3$ & Cukup valid \\
\hline $1 \leq R T V<2$ & Tidak valid
\end{tabular}

(Waluyo, 2017: 33)

\section{Ketrampilan literasi lingkungan}

Untuk mengukur ketrampilan literasi lingkungan peserta didik dapat menggunakan pedoman penskoran Self assesment dan peer assesment, tes, dan hasil kegiatan motorik siswa.

\section{a. Self assesment dan peer assesment}

Dalam penelitian ini pengelolaaan data yang digunakan untuk mengetahui tingkat sikap dan ketrampilan siswa tentang literasi lingkungan melalui data lembar self assesmen dan peer assesment. Menurut menurut (Kusumaningrum \& Muslihasari, 2019) untuk menghitung angket respon siswa terhadap penerapan self assesmen dan peer assesment untuk menumbuhkan kesadaran sikap dan ketrampilan siswa tentang literasi
Cukup $=\quad$ Apabila memperoleh skor $63-73$

Baik $=$ Apabila memperoleh skor $74-84$

Sangat baik = Apabila memperoleh skor $85-100$

\section{a. Tes}

Tes digunakan berupa soal pretest dan soal posttest yang digunakan untuk mengetahui persentase keterlaksanaan pembelajaran menggunakan LKS IPA tema 8 subtema 2 "siklus air" yang berbasis inkuiri untuk meningkatkan ketrampilan literasi lingkungan siswa kelas V SDN 5 Babadan. Skor dapat dihitung sebagai berikut:

skor akhir $=\frac{\text { jumlah nomor yang benar }}{10} \times 100$

(Kusumaningrum \& Muslihasari, 2019)

Setelah didapat skor akhir maka langkah selanjutnya adalah

lingkungan pada pembelajaran IPA tema 8 subtema 2 pembelajaran 1 siswa SDN 5 Babadan sebagai berikut:

Dengan kategori sebagai berikut: mengkategorikan apakah telah mencapai kategori yang diinginkan ataukah belum. Pedoman kategori hasil tes dapat dilihat pada Tabel 5 berikut.

$$
\text { Kurang }=\text { Apabila }
$$

memperoleh skor kurang dari 63 
Tabel 5 Kategori Hasil Tes

\begin{tabular}{ll}
\hline Rentang nilai & kategori \\
\hline$\leq 75,05$ & Sangat tinggi \\
\hline $50-75,05$ & Tinggi \\
\hline 24,95 & Rendah \\
\hline$<24,95$ & Sangat rendah \\
\hline
\end{tabular}

Adaptasi: kusumaningrum \& Muslihasari (2019)

\section{c. Kegiatan motorik siswa}

Untuk memperoleh data dari hasil motorik siswa dapat dihitung dengan rumus berikut:

skor akhir $=\frac{\text { skor yang diperoleh }}{\text { jumlah skor maksimal }} \times 100$

(Kusumaningrum \& Muslihasari, 2019)

Keterangan:

Sangat baik = apabila memperoleh skor $85-100$

Baik = apabila memperoleh skor

74-84

Cukup = apabila memperoleh skor 63-73

Kurang = apabila memperoleh skor kurang dari 63

(Kusumaningrum \& Muslihasari, 2019: 26)

\section{Hasil dan Pembahasan}

\section{Hasil Uji Coba}

Peneliti melakukan uji coba produk ini secara daring (online) dikarenakan adanya pandemi COVID 19 yang telah melanda seluruh negara di dunia termasuk di negara Indonesia. Pemerintah pada saat itu mengeluarkan peraturan dimana semua jenjang sekolah diliburkan termasuk jenjang Sekolah Dasar. Uji coba produk secara online yang diakukan oleh peneliti sebenarnya sangat berbeda sekali dengan metode dan langkah yang sudah direncanakan oleh peneliti di awal.

Seharusnya siswa melakukan pembelajaran di sekolah, melakukan praktek dan dibimbing langsung oleh peneliti disini siswa melakukan pembelajaran dirumah melakukan praktek dirumah dan dibimbing oleh peneliti melalui online via Whatsapp, sehingga uji coba yang dilakukan sangat mebutuhkan tenaga dan pikiran lebih ekstra menurut peneliti dikarenakan harus membuat video, power poin dan selanjutnya di kirim melalui whatsapp dalam menerangkan materi-materi yang akan dipelajari, serta harus membimbing siswa dalam melakukan percobaan dari awal sampai akhir melalui whatsapp. Uji coba produk pada pengembangan ini menggunakan beberapa tahapan yang dilakukan menggunakan google formulir diantaranya pretest dan postest, self assesment dan peerassesment, dan kegiatan motorik siswa yang dapat dipaparkan sebagai berikut:

\section{a. Hasil Validasi Produk}

Data hasil uji validasi meliputi data hasil validasi dari dosen ahli dan guru kelas. Data validasi ini meliputi penilaian produk LKS, penilaian soal tes, dan penilaian RPP. 
Tabel 6 Data Hasil Penilaian Produk LKS

\begin{tabular}{lcccccccc}
\hline No Validator & \multicolumn{6}{c}{ Aspek } & \multicolumn{2}{c}{ Total } \\
\cline { 2 - 8 } & $\begin{array}{c}\text { Kompo } \\
\text { nen } \\
\text { LKS }\end{array}$ & $\begin{array}{c}\text { kuriku } \\
\text { lum }\end{array}$ & $\begin{array}{c}\text { Keber } \\
\text { makna } \\
\text { an } \\
\text { LKS }\end{array}$ & $\begin{array}{c}\text { Penent } \\
\text { uan } \\
\text { judul } \\
\text { LKS }\end{array}$ & $\begin{array}{c}\text { Penulis } \\
\text { an } \\
\text { LKS }\end{array}$ & $\begin{array}{c}\text { Tata } \\
\text { bahasa }\end{array}$ & $\begin{array}{c}\text { Tampil } \\
\text { an } \\
\text { LKS }\end{array}$ \\
\hline $1 . \quad$ Dosen ahli & 4 & 8 & 12 & 12 & 11 & 8 & 8 & 63 \\
\hline $2 . \quad$ Guru kelas & 4 & 8 & 11 & 12 & 12 & 8 & 8 & 63 \\
\hline Total & 8 & 16 & 23 & 24 & 23 & 16 & 16 & 126 \\
\hline Rata-rata & 4 & 8 & 11 & 12 & 11 & 8 & 8 & 63 \\
\hline Persentase & $100 \%$ & $100 \%$ & $91 \%$ & $100 \%$ & $91 \%$ & $100 \%$ & $100 \%$ & $98 \%$ \\
\hline Kategori & $\begin{array}{c}\text { Sangat } \\
\text { layak }\end{array}$ & $\begin{array}{c}\text { Sangat } \\
\text { layak }\end{array}$ & $\begin{array}{c}\text { Sangat } \\
\text { layak }\end{array}$ & $\begin{array}{c}\text { Sangat } \\
\text { layak }\end{array}$ & $\begin{array}{c}\text { Sangat } \\
\text { layak }\end{array}$ & $\begin{array}{c}\text { Sangat } \\
\text { layak }\end{array}$ & $\begin{array}{c}\text { Sangat } \\
\text { layak }\end{array}$ & $\begin{array}{c}\text { Sangat } \\
\text { layak }\end{array}$ \\
\hline
\end{tabular}

Tabel 6 di atas menunjukkan hasil penilaian produk LKS oleh dosen ahli materi dan guru kelas diperoleh jumlah total skor 126 serta persentase $98 \%$ dinyatakan dalam kriteria sangat layak. Penilaian produk LKS ini terdapat komentar dan masukan oleh dosen ahli dan guru kelas yaitu perbaikan peta konsep pada LKS dengan rincian yang lebih detail agar mempermudah siswa memahami materi yang akan dipelajari dan penambahan materi pada LKS diperbanyak dan lebih spesifik.

Tabel 7 Data Hasil Penilaian Soal Tes

\begin{tabular}{|c|c|c|c|c|c|c|c|}
\hline \multirow[t]{2}{*}{ No } & \multirow[t]{2}{*}{ validator } & \multicolumn{3}{|c|}{ Aspek } & \multirow{2}{*}{$\begin{array}{l}\text { Jumlah } \\
\text { skor }\end{array}$} & \multirow[t]{2}{*}{ persentase } & \multirow[t]{2}{*}{ kategori } \\
\hline & & Materi & konstruksi & $\begin{array}{c}\text { Penggunaan } \\
\text { bahasa }\end{array}$ & & & \\
\hline 1. & $\begin{array}{l}\text { Dosen } \\
\text { ahli }\end{array}$ & 24 & 29 & 15 & 68 & $97,1 \%$ & \multirow{2}{*}{$\begin{array}{c}\text { Sangat } \\
\text { valid dapat } \\
\text { digunakan } \\
\text { tanpa revisi }\end{array}$} \\
\hline 2. & $\begin{array}{l}\text { Guru } \\
\text { kelas }\end{array}$ & 23 & 30 & 14 & 67 & $95,7 \%$ & \\
\hline
\end{tabular}

Tabel 7 di atas menunjukkan hasil penilaian soal tes oleh dosen ahli materi dan guru kelas diperoleh dengan kategori sangat valid dan dapat digunakan tanpa revisi. Penilaian soal tes ini digunakan untuk pretest dan postest.

Tabel 8 Data Hasil Penilaian RPP

\begin{tabular}{cccc}
\hline Aspek & Jumlah setiap aspek & Skor maksimal & Rata-rata komponen \\
\hline Format & 8 & 8 & 4 \\
\hline Isi & 11 & 12 & 3,67 \\
\hline Bahasa & 11 & 12 & 3,67 \\
\hline Jumlah total & & 30 & \\
\hline Skor maksimal & 32 & & \\
\hline $\begin{array}{c}\text { Rara-rata total } \\
\text { validitas }\end{array}$ & & $\mathbf{3 , 7 8}$ \\
\hline kriteria & & Valid \\
\hline
\end{tabular}

Tabel 8 di atas menunjukkan hasil jumlah total skor 30 dengan skor penilaian RPP oleh guru kelas diperoleh maksimal 32 dan menunjukkan rata-rata 81 | Pengembangan LKS Berbasis Inkuiri Terbimbing untuk memberdayakan Literasi 
total validitas 3,7 dengan kriteria valid. Penilaian RPP ini hanya di lakukan kepada guru kelas saja.

\section{b. Uji coba produk kelompok kecil}

Uji coba produk kelompok kecil melibatkan 6 siswa dilaksanakan pada tanggal 25 bulan maret 2020. Adapun kegiatan dalam uji coba ini adalah dengan pretest dan postest serta mengisi tanggapan pada angket respon terhadap bahan ajar LKS. Hasil postest akan di bandingkan dengan hasil pretest yang telah dilakukan sehingga akan diketahui seberapa jauh efek atau pengaruh dari pengajaran yang telah dilakuakan, sekaligus dapat diketahui bagian-bagian mana materi yang masih belum dipahami oleh sebagian besar siswa. Hasil pretest dan postest pada uji coba kelompok kecil dapat dilihat pada Tabel
9 berikut.

Tabel 9 Hasil Pretest Dan Postest Kelompok Kecil

\begin{tabular}{ccccc}
\hline \multirow{2}{*}{ No } & \multirow{2}{*}{ Nama siswa } & \multicolumn{2}{c}{ Pretest } & Postest \\
\cline { 3 - 5 } & & Persentase & kategori & persentase \\
\hline 1 & ES & $60 \%$ & Tinggi & $90 \%$ \\
\hline 2 & ZA & $40 \%$ & Rendah & $80 \%$ \\
\hline 3 & KE & $30 \%$ & Rendah & $80 \%$ \\
\hline 4 & TA & $60 \%$ & Tinggi & $70 \%$ \\
\hline 5 & RO & $50 \%$ & Tinggi & $90 \%$ \\
\hline 6 & CH & $70 \%$ & Tinggi & $100 \%$ \\
\hline \multicolumn{2}{c}{ Jumlah rata-rata } & $\mathbf{5 2 \%}$ & Tinggi & $\mathbf{8 5 \%}$ \\
\hline \multicolumn{5}{r}{} \\
\hline
\end{tabular}

Hasil pretest dan postest di atas menunjukkan bahwa terdapat peningkatan nilai pada siswa setelah melakukan pembelajara dengan menggunakan bahan ajar LKS berbasis inkuiri terbimbing untuk memberdayakan literasi lingkungan dengan peningkatan $33 \%$.
Hasil tanggapan siswa terhadap angket respon pada bahan ajar LKS bertujuan untuk mengetahui tingkat kelayakan bahan ajar LKS saat digunakan dalam proses pembelajaran, adapun hasil tanggapan tersebut adalah sebagai berikut:

Tabel 10 Hasil Respon Siswa Kelompok Kecil

\begin{tabular}{|c|c|c|c|c|c|c|c|}
\hline \multirow[t]{2}{*}{ No } & \multirow[t]{2}{*}{ Nama Siswa } & \multicolumn{5}{|c|}{ Indikator } & \multirow{2}{*}{$\begin{array}{c}\text { Jumlah } \\
\text { skor }\end{array}$} \\
\hline & & 1 & 2 & 3 & 4 & 5 & \\
\hline 1 & ES & 6 & 3 & 3 & 4 & 3 & 19 \\
\hline 2 & $\mathrm{ZA}$ & 6 & 3 & 4 & 4 & 3 & 20 \\
\hline 3 & $\mathrm{KE}$ & 6 & 3 & 3 & 4 & 3 & 19 \\
\hline 4 & TA & 6 & 3 & 3 & 4 & 3 & 19 \\
\hline 5 & $\mathrm{RO}$ & 6 & 3 & 3 & 4 & 2 & 18 \\
\hline 6 & $\mathrm{CH}$ & 6 & 3 & 4 & 4 & 3 & 20 \\
\hline \multicolumn{7}{|c|}{ Jumlah skor } & 115 \\
\hline \multicolumn{7}{|c|}{ Rata-rata } & 19,16667 \\
\hline \multicolumn{7}{|c|}{ Persentase } & $95,8 \%$ \\
\hline \multicolumn{7}{|c|}{ kategori } & $\begin{array}{c}\text { Sangat } \\
\text { baik }\end{array}$ \\
\hline
\end{tabular}


Berdasarkan penjabaran di atas dapat disimpulkan bahwa respon siswa terhadap LKS berbasis inkuiri terbimbing untuk memberdayakan literasi lingkungan siswa dapat meningkatkan minat belajar siswa dan dapat diterapkan di kelompok besar karena persentase skor yang diperoleh 95,8 \% dengan kategori sangat baik.

\section{c. Uji Coba Produk Kelompok Besar}

Uju coba produk dilaksanakan pada tanggal 4 bulan April 2020. Uji coba produk melibatkan 20 siswa kelas $\mathrm{V}$ di
SDN 5 Babadan kecamatan Ngajum. Kegiatan pada uji coba ini dilakukan dengan pengajaran oleh peneliti kepada siswa dengan menggunakan LKS. Pretest dan postest diberikan kepada siswa pada kegiatan implementasi ini. Hasil pretest akan dibandingkan dengan hasil postest sehingga akan diketahui seberapa jauh efek atau pengaruh dari pengajaran dengan menggunakan LKS berbasis inkuiri terbimbing yang telah diterapkan. Hasil pretest dan postest pada uji kelompok besar dapat dilihat pada Tabel 11 berikut.

Tabel 11 Hasil Pretest Dan Postest Kelompok Besar

\begin{tabular}{cccccc}
\hline \multirow{2}{*}{ No } & Nama siswa & \multicolumn{2}{c}{ Pretest } & \multicolumn{2}{c}{ Postest } \\
\cline { 2 - 6 } & & Persentse & Kategori & Persentase & Kategori \\
\hline 1 & RE & $0 \%$ & Sangat rendah & $60 \%$ & Tinggi \\
\hline 2 & CH & $90 \%$ & Sangat tinggi & $100 \%$ & Sangat tinggi \\
\hline 3 & FA & $60 \%$ & Tinggi & $70 \%$ & Tinggi \\
\hline 4 & DA & $50 \%$ & Rendah & $70 \%$ & Tinggi \\
\hline 5 & MU & $10 \%$ & Sangat rendah & $60 \%$ & Tinggi \\
\hline 6 & KE & $60 \%$ & Tinggi & $80 \%$ & Sangat tinggi \\
\hline 7 & AZ & $60 \%$ & Tinggi & $80 \%$ & Tinggi \\
\hline 8 & MI & $30 \%$ & Rendah & $70 \%$ & Tinggi \\
\hline 9 & AN & $50 \%$ & Rendah & $80 \%$ & Sangat tinggi \\
\hline 10 & IK & $70 \%$ & Tinggi & $90 \%$ & Tinggi \\
\hline 11 & RE & $30 \%$ & Rendah & $60 \%$ & Tinggi \\
\hline 12 & SA & $20 \%$ & Sangat rendah & $70 \%$ & Tinggi \\
\hline 13 & ES & $60 \%$ & Tinggi & $90 \%$ & Sangat tinggi \\
\hline 14 & YE & $50 \%$ & Rendah & $90 \%$ & Sangat tinggi \\
\hline 15 & AH & $30 \%$ & Rendah & $70 \%$ & Tinggi \\
\hline 16 & ZA & $60 \%$ & Tinggi & $80 \%$ & Sangat tinggi \\
\hline 17 & NA & $70 \%$ & Tinggi & $80 \%$ & Sangat tinggi \\
\hline 18 & AD & $50 \%$ & Rendah & $80 \%$ & Sangat tinggi \\
\hline 19 & EK & $40 \%$ & Rendah & $70 \%$ & Tinggi \\
\hline 20 & HE & $50 \%$ & Rendah & $80 \%$ & Sangat tinggi \\
\hline Jumlah rata-rata & $\mathbf{4 7 \%}$ & kurang & $\mathbf{7 7 \%}$ & Baik \\
\hline
\end{tabular}

Tabel 11 di atas menunjukkan bahwa hasil pretest dan postest terdapat peningkatan nilai pada siswa setelah melakukan pembelajaran dengan menggunakan LKS berbasi inkuiri terbimbing untuk memberdayakan literasi lingkungan dengan peningkatan $30 \%$.
Hasil tanggapan siswa terhadap angket respon pada bahan ajar LKS bertujuan untuk mengetahui tingkat kelayakan bahan ajar LKS saat digunakan dalam proses pembelajaran, adapun hasil tanggapan tersebut dapat di lihat pada Tabel 12 di bawah ini. 
Tabel 12 Hasil Respon Siswa Kelompok Besar

\begin{tabular}{lcc}
\hline No & $\begin{array}{c}\text { Nama } \\
\text { Siswa }\end{array}$ & Jumlah skor \\
\hline 1 & HE & 19 \\
\hline 2 & EK & 18 \\
\hline 3 & AD & 20 \\
\hline 4 & NA & 17 \\
\hline 5 & ZA & 20 \\
\hline 6 & AH & 18 \\
\hline 7 & YE & 20 \\
\hline 8 & ES & 20 \\
\hline 9 & SA & 19 \\
\hline 10 & RE & 17 \\
\hline 11 & IK & 20 \\
\hline 12 & AN & 17 \\
\hline 13 & MI & 20 \\
\hline 14 & AS & 18 \\
\hline 15 & KE & 20 \\
\hline 16 & MU & 18 \\
\hline 17 & DA & 18 \\
\hline 18 & FA & 20 \\
\hline 19 & CH & 20 \\
\hline 20 & RE & 17 \\
\hline Jumlah skor & $\mathbf{3 7 6}$ \\
\hline & Rata-rata & $\mathbf{1 8 , 8}$ \\
\hline & Persentase & Sangat baik \\
\hline & kategori & \\
\hline & & \\
\hline
\end{tabular}

Berdasarkan penjabaran di atas dapat disimpulkan bahwa jumlah seluruh skor respon siswa terhadap bahan ajar LKS berbasis inkuiri terbimbing untuk memberdayakan literasi lingkungan siswa adalah 376 yang memiliki rata-rata 18,8 dengan persentase $94 \%$ dan di kategorikan sangat baik.

\section{d. Hasil uji Self assesment}

Penilaian literasi lingkungan ranah afektif dapat menggunakan self assesment secara bersama. Lembar penskoran ini diisi oleh siswa untuk menilai sikap dan perilaku diri sendiri terhadap lingkungan dapat dilihat pada Tabel 13 di bawah ini.

Tabel 13 Hasil Penilaian Self Assesment

\begin{tabular}{ccccc}
\hline No & $\begin{array}{c}\text { Nama } \\
\text { penilai }\end{array}$ & $\begin{array}{c}\text { Jumlah } \\
\text { skor }\end{array}$ & Persentase & kategori \\
\cline { 3 - 5 } & & & & \\
\hline 1 & FA & 49 & $89 \%$ & Sangat baik \\
\hline 2 & NA & 50 & $90,9 \%$ & Sangat baik \\
\hline 3 & RE & 53 & $96,3 \%$ & Sangat baik \\
\hline 4 & ES & 54 & $98,1 \%$ & Sangat baik \\
\hline 5 & SA & 47 & $85,4 \%$ & Sangat baik \\
\hline 6 & CH & 51 & $92,7 \%$ & Sangat baik \\
\hline 7 & DA & 48 & $87,2 \%$ & Sangat baik \\
\hline 8 & MU & 48 & $87,2 \%$ & Sangat baik \\
\hline 9 & EK & 48 & $87,2 \%$ & Sangat baik \\
\hline 10 & AN & 55 & $100 \%$ & Sangat baik \\
\hline 11 & KE & 53 & $96,3 \%$ & Sangat baik \\
\hline
\end{tabular}




\begin{tabular}{lcccc}
\hline 12 & HE & 55 & $100 \%$ & Sangat baik \\
\hline 13 & IC & 54 & $98,1 \%$ & Sangat baik \\
\hline 14 & AH & 50 & $90,9 \%$ & Sangat baik \\
\hline 15 & MI & 51 & $92,7 \%$ & Sangat baik \\
\hline 16 & AD & 53 & $96,3 \%$ & Sangat baik \\
\hline 17 & RE & 52 & $94,5 \%$ & Sangat baik \\
\hline 18 & YE & 52 & $94,5 \%$ & Sangat baik \\
\hline 19 & ZA & 50 & $90,9 \%$ & Sangat baik \\
\hline
\end{tabular}

Tabel 13 di atas menunjukkan bahwa hasil penskoran self assesment diperoleh jumlah rata-rata skor 50,9 dengan persentase $93 \%$ dan di kategorikan dengan sangat baik.

\section{e. Hasil uji Peer assesment}

Pedoman penskoran sikap dan perilaku terhadap lingkungan atau peer assesment ini di isi oleh teman sejawat, dapat dilihat pada Tabel 14 di bawah ini.

Tabel 14 Hasil Penilaian Peer Assesment

\begin{tabular}{ccccc}
\hline No & $\begin{array}{c}\text { Nama } \\
\text { penilai }\end{array}$ & $\begin{array}{c}\text { Jumlah } \\
\text { skor }\end{array}$ & Persentase & kategori \\
\cline { 3 - 5 } & & \multicolumn{3}{c}{} \\
\hline 1 & ES & 48 & $80 \%$ & Baik \\
\hline 2 & AH & 60 & $100 \%$ & Sangat baik \\
\hline 3 & AZ & 60 & $100 \%$ & Sangat baik \\
\hline 4 & ME & 60 & $100 \%$ & Sangat baik \\
\hline 5 & ZA & 59 & $98,3 \%$ & Sangat baik \\
\hline 6 & IK & 56 & $93,3 \%$ & Sangat baik \\
\hline 7 & AD & 48 & $80 \%$ & Baik \\
\hline 8 & AN & 60 & $100 \%$ & Sangat baik \\
\hline 9 & MI & 59 & $98,3 \%$ & Sangat baik \\
\hline 10 & SA & 58 & $96,6 \%$ & Sangat baik \\
\hline 11 & EK & 51 & $85 \%$ & Sangat baik \\
\hline 12 & KE & 43 & $71,6 \%$ & Cukup \\
\hline 13 & MU & 47 & $78,3 \%$ & baik \\
\hline 14 & HE & 57 & $95 \%$ & Sangat baik \\
\hline 15 & NA & 50 & $83,3 \%$ & baik \\
\hline 16 & RE & 54 & $90 \%$ & Sangat baik \\
\hline 17 & CH & 59 & $98,3 \%$ & Sangat baik \\
\hline 18 & YE & 57 & $95 \%$ & Sangat baik \\
\hline 19 & DA & 58 & $96,6 \%$ & Sangat baik \\
\hline Jumlah rata-rata & $\mathbf{5 , 4 9}$ & $\mathbf{9 2 \%}$ & Sangat baik \\
\hline & & & &
\end{tabular}

Tabel 14 di atas menunjukkan bahwa hasil penskoran peer assesment diperoleh jumlah rata-rata skor 5,49 dengan persentase $92 \%$ dan dikategorikan sangat baik.

\section{f. Hasil Penilaian Motorik Siswa}

Hasil penilaian motorik pada pengembangan bahan ajar LKS ini dapat dilihat pada Tabel 15 berikut. 
Tabel 15 Hasil Penilaian Kegiatan Motorik Siswa

\begin{tabular}{|c|c|c|c|}
\hline No & Nama siswa & Skor akhir & Persentase \\
\hline 1 & $\mathrm{RE}$ & 22 & $81,4 \%$ \\
\hline 2 & $\mathrm{CH}$ & 27 & $100 \%$ \\
\hline 3 & FA & 24 & $88,8 \%$ \\
\hline 4 & DA & 27 & $100 \%$ \\
\hline 5 & MU & 24 & $88,8 \%$ \\
\hline 6 & $\mathrm{KE}$ & 27 & $100 \%$ \\
\hline 7 & $\mathrm{AS}$ & 27 & $100 \%$ \\
\hline 8 & MI & 25 & $92,5 \%$ \\
\hline 9 & $\mathrm{AN}$ & 22 & 81,4 \\
\hline 10 & IK & 27 & $100 \%$ \\
\hline 11 & $\mathrm{RE}$ & 24 & $88,8 \%$ \\
\hline 12 & SA & 26 & 96,2 \\
\hline 13 & $\mathrm{ES}$ & 27 & $100 \%$ \\
\hline 14 & YE & 27 & $100 \%$ \\
\hline 15 & $\mathrm{AH}$ & 26 & $96,2 \%$ \\
\hline 16 & $\mathrm{ZA}$ & 26 & $96,2 \%$ \\
\hline 17 & NA & 25 & $92,5 \%$ \\
\hline 18 & $\mathrm{AD}$ & 24 & $88,8 \%$ \\
\hline 19 & EK & 20 & $74 \%$ \\
\hline 20 & $\mathrm{HE}$ & 25 & $92,5 \%$ \\
\hline \multicolumn{2}{|c|}{ Jumlah rata-rata } & 25,1 & $97 \%$ \\
\hline \multicolumn{2}{|c|}{ Kategori } & \multicolumn{2}{|c|}{ Sangat baik } \\
\hline
\end{tabular}

Tabel 15 di atas menunjukkan hasil penilaian kegiatan motorik siswa yang dilakukan oleh peneliti sebagai guru diperoleh jumlah rata-rata skor akhir adalah 25,1 dan jumlah rata-rata total persentase $97 \%$ dengan kategori sangat baik.

\section{Revisi tahap I}

Revisi tahap pertama mengacu pada masukan atau saran terhadap dosen ahli materi dan guru kelas agar dapat memberikan tentang kualitas teknis dan pemanfaatan LKS. Berikut hasil revisi menghasilkan:

a. Dosen ahli materi

Perbaikan peta konsep pada LKS dengan rincian yang lebih detail agar mempermudah siswa memahami materi yang akan dipelajari. Tampilan peta konsep pada LKS sebelum dan sesudah revisi dapat dilihat pada Tabel 16 berikut. 
Tabel 16 Tampilan Peta Konsep LKS Sebelum dan Sesudah Revisi

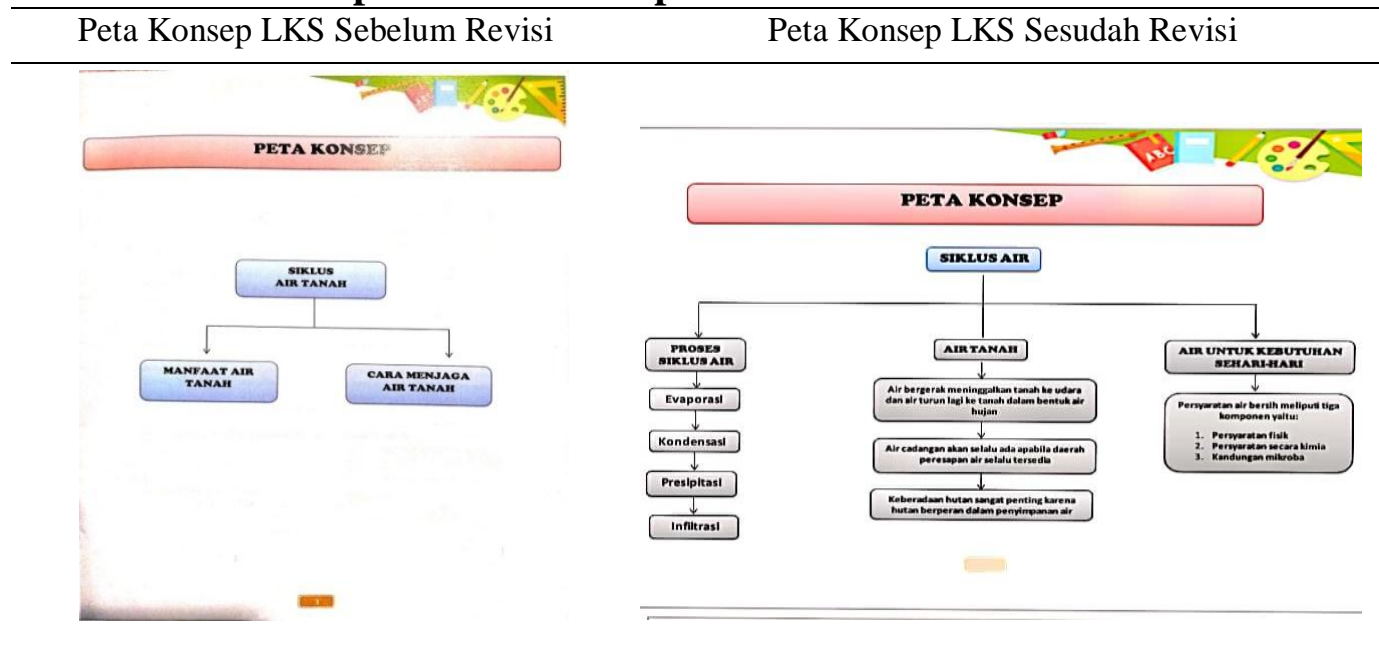

b. Guru kelas

Penambahan materi pada LKS diperbanyak dan lebih spesifik agar siswa dapat dengan mudah memahami. Tampilan materi pada LKS sebelum dan sesudah direvisi dapat dilihat pada Tabel 17 berikut.

Tabel 17 Materi Pada LKS Sebelum dan Sesudah Revisi Materi LKS Sebelum Revisi Materi LKS Sesudah Revisi
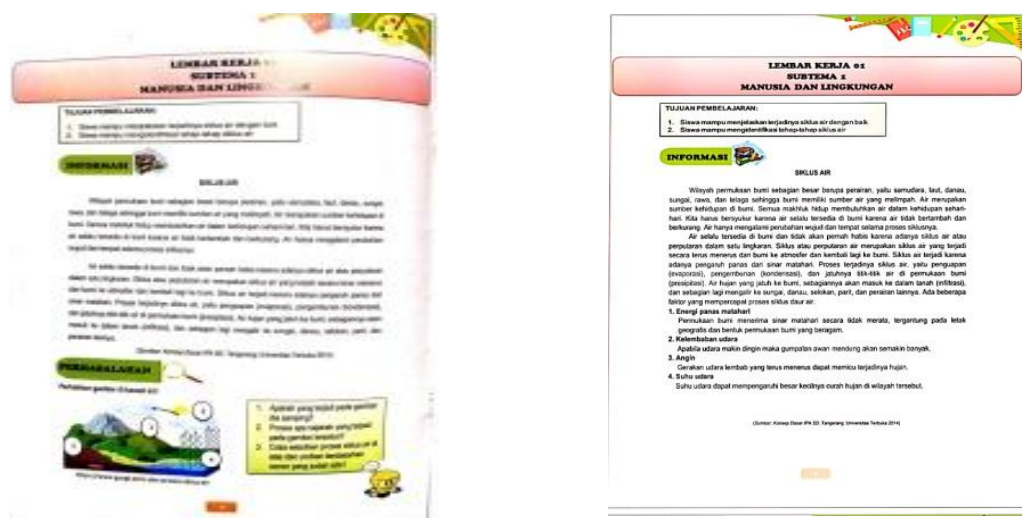


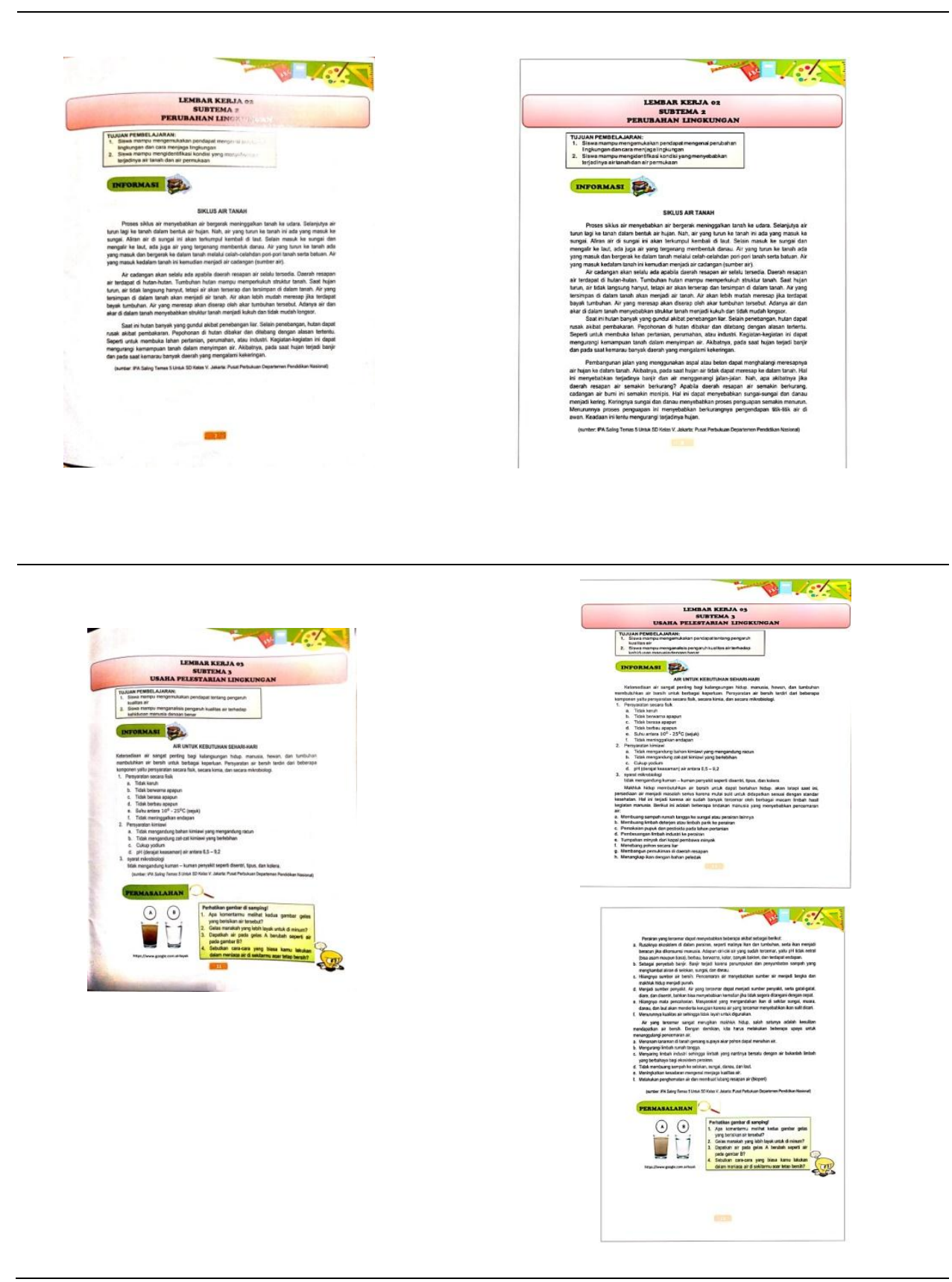

\section{Revisi Tahap II}

Revisi tahap II dilakukan mengacu pada saran, komentar dan hasil observasi saat uji coba kelompok besar dan berdasarkan pengamatan dari wali kelas. Adapun revisi yang dilakukan dalam tahap II ini yaitu buku LKS yang digunakan secara berkelompok seharusnya setiap siswa mempunyai agar tidak saling berebut. LKS yang digunakan dibuat di buat dari kertas tipis buram saja agar bisa menghemat biaya dan semua siswa bisa memiliki.

\section{Pembahasan}

Penelitian ini berjudul "Pengembanagn Lembar Kerja Siswa Berbasis Inkuiri Terbimbing Untuk Memberdayakan Literasi Lingkungan Pada Siswa Kelas V SD" pada pembahasan ini ada tiga hal pokok yang akan dibahas sesuai dengan tujuan penelitian yaitu: 1) kevalidan LKS 
berbasis inkuiri terbimbing untuk siswa kelas V SDN 5 Babadan, 2) keterbacaan LKS bebasis inkuiri terbimbing untuk siswa kelas V SDN 5 Babadan, 3) LKS bebasis inkuiri terbimbing kelas $V$ SDN 5 Babadan dapat memberdayakan ketrampilan literasi lingkungan pada siswa. Model pengembangan yang digunakan dalam penelitian ini adalah model pengembangan dari Borg dan Gall yang sudah dimodifikasi oleh Sugiyono dan hanya dibatasi tujuh langkah penelitian dan pengembangan, yaitu potensi dan masalah, pengumpulan data, desain produk, validasi desain, perbaikan desain, uji coba produk, dan revisi produk (Sugiono, 2010). Berikut penjabaran hasil analisis kelayakan penelitian pengembangan LKS ini:

\section{Kevalidan LKS berbasis inkuiri terbimbing untuk siswa kelas $\mathrm{V}$ SDN 5 Babadan}

Kevalidan LKS dalam penelitian ditinjau dari penilaian validator ahli materi dan guru kelas. Pada penelitian ini telah dikembangkan LKS berbasis inkuiri terbimbing untuk memberdayakan literasi lingkungan siswa pada matapelajaran IPA materi tentang siklus air. Kelayakan LKS berdasarkan penilaian validator dan guru kelas dapat dilihat dari ketiga aspek yaitu didaktif, konstruksi dan teknis, hal ini menunjukkan bahwa LKS yang sisusun oleh peneliti sudah dinyatakan oleh validator untuk digunakan dalam pembelajaran. Persentase menunjukkan $98 \%$ yang berarti LKS sangat layak digunakan dalam pembelajaran sesuai dengan pendapat Kaligis \& Darmodjo (1993).

Kevalidan LKS juga dapat dilihat dari sudut pandang siswa yaitu sebagai sarana belajar baik diruang praktik, maupun diluar kelas, sehingga siswa berpeluang besar untuk mengembangkan kemampuannya, menerapkan pengetahuan, melatih keterampilan, memproses sendiri dengan bimbingan guru, sedangkan dari sudut pandang guru melalui LKS berbasis inkuiri terbimbing untuk memberdayakan literasi lingkungan ini dalam menyelenggarakan kegiatan belajar mengajar sudah menerapkan metode untuk menciptakan suasana kelas yang aktif, siswa akan merasa diberikan tanggung jawab untuk menyelesaikan siatu tugas dan memecahkan masalah yang ada dalam LKS tersebut sesuai pendapat Hafshoh, (2017).

\section{Keterbacaan LKS bebasis inkuiri terbimbing untuk siswa kelas $V$ SDN 5 Babadan}

LKS dalam pengembangan ini berisi mata pelajaran IPA tema 8 Lingkungan Sahabat Kita pada materi siklus air dilengkapi dengan latihan soal. Materi yang ada dalam LKS ini disusun sedemikian rupa supaya siswa dapat merasa terbimbing dan dapat memotivasi siswa untuk menjawab latihan soal yang ada dengan mudah. Keterbacaan LKS dapat dilihat dari lima macam bentuk LKS pada umumnya yang digunakan oleh siswa antara lain; 1) LKS membantu siswa menemukan konsep, 2) membantu siswa menerapkan dan menintegrasikan berbagai konsep yang telah ditemukan, 3) berfungsi sebagai penuntun belajar, 4) berfungsi sebagai penguat, dan 5) berfungsi sebagai petunjuk praktikum. Hasil uji keterbacaan LKS setelah melakukan pembelajaran pada uji coba kelas kecil 
yang dilakukan oleh 6 siswa secara acak menunjukkan persentase 95,8 \% dengan kategori sangat baik, sedangkan pada uji coba kelompok besar yang dilakukan oleh 20 siswa secara acak menunjukkan persentase $94 \%$ dengan kategori sangat baik sesuai dengan pendapat Prastowo (2014).

\section{LKS Berbasis Inkuiri Terbimbing Kelas V SDN 5 Babadan Dapat Memberdayakan Ketrampilan Literasi Lingkungan Pada Siswa.}

Inkuiri terbimbing tidak hanya menuntut siswa untuk dapat melakukan investigasi secara mandiri, tetapi juga menuntut siswa untuk mampu memahami implikasi suatu hasil eksperimen. Inkuiri terbimbing adalah kegiatan siswa sebagai peneliti dengan bimbingan guru, yang melatih siswa agar mampu berperan sebagai problem Solver. LKS inkuiri terbimbing dapat meningkatkan literasi lingkungan pada siswa karena dapat melatih siswa untuk membangun jawaban dan berpikir cerdas dalam menemukan berbagai alternatif solusi atas permasalahan yang diajukan oleh guru, mengembangkan keterampilan pemahaman konsep, membagun rasa bertanggung jawab, dan melatih proses penyampaian konsep yang ditemukan. Peningkatan belajar dapat dilihat dari uji pretest dan postest yang telah dilakukan oleh peneliti menunjukkan bahwa terdapat peningkatan $30 \%$ dapat dilihat pada Tabel 4.6 yang menunjukan bahwa dengan kategori sangat baik sesuai dengan pendapat (Khasanah, 2016).

Peningkatan literasi lingkungan dapat dilihat dari hasil penilaian self assesment dan peer assesment yang sudah diujikan oleh peneliti agar dapat menilai sikap perilaku diri sendiri dan teman sejawat terhadap literasi lingkungan. Penilaian self assesment yang sudah dilakukan oleh peneliti menunjukkan persentase $93 \%$, sedangkan penilaian peer assesment menunjukkan persentase sebesar $92 \%$ dengan memiliki kategori yang sangat baik dimana siswa telah memiliki sikap tentang literasi lingkungan dengan sangat baik, seperti yang sudah di jelaskan oleh (Kusumaningrum, 2018).

Peningkatan literasi lingkungan juga dapat dilihat dari hasil penilaian motorik pada siswa dimana siswa dalam mempersiapkan, melaksanakan, serta menjaga kebersihan dalam melakukan percobaan menunjukkan hasil kategori sangat baik yaitu memiliki total persentase sebanyak $97 \%$ dimana hasil tersebut telah memenuhi standar atau komponen dari literasi lingkungan yang telah dipaparkan oleh (UNESCO, 2006) yaitu dalam menyelidiki, manganalisis, menerapkan, menjelaskan, memanfaatkan dan menjaga kebersihan terhadap lingkungan disekitarnya. 


\section{Kesimpulan}

Berdasarkan analisis data dan pembahasan pada bab IV dapat diambil kesimpulan bahwa:

1. Kualitas LKS dapat dilihat dari kevalidan LKS yang telah di nilai oleh validator ahli materi dan guru kelas, ditinjau dari aspek kelayakan baik dari segi komponen LKS, kurikulum, kebermaknaan LKS, penentuan judul LKS, penulisan LKS, tata bahasa, tampilan LKS, dan secara keseluruhan baik dan sangat layak digunakan dalam pembelajaran kelas $\mathrm{V}$ yang sudah divalidasi oleh dosen ahli materi dan guru kelas.

2. Hasil penggunaan LKS ini dapat dilihat dari angket respon siswa yang memperoleh jumlah skor sebesar 376 dengan rata-rata 18,8 dengan persentase $94 \%$ dikategorikan dengan "sangat baik" dalam penggunaan bahan ajar LKS. Setelah melakukan pembelajaran menggunakan LKS berbasis inkuiri terbimbing untuk memberdayakan literasi lingkungan dan ketrampilan motorik siswa kelas SDN 5 Babadan kecamatan Ngajum.

3. Kategori penilaian ketrampilan literasi lingkungan pada pengembangan LKS ini juga menunjukkan hasil yang sangat baik. Dilihat dari hasil penilaian self assesment yang sudah dilakukan oleh peneliti menunjukkan persentase $93 \%$, sedangangkan penilaian peer assesment menunjukkan persentase sebesar 92 \% dengan memiliki kategori yang sangat baik.

\section{Daftar Pustaka}

A. Prastowo, Analisis Pembelajaran Tematik Terpadu. Jakarta: Kencana, 2019.

D. Kusumaningrum and A. Muslihasari, "Instrumen Penilaian Literasi Lingkungan Berbasis Assesment Autentik Kelas 5 SD Tema 8," 2019.

R. Amini, "Pengembangan Pembelajaran Pendidikan Lingkungan Berbasis Outdoor untuk Calon Guru Sekolah Dasar," UPI BAndung, 2010.

Sugiyono, Metode Penelitian Pendidikan Pendekatan Kuantitatif, kualitatif, dan R\&D. Bandung: Alfabeta, 2010.

S. Arikunto, Prosedur Penelitian (Suatu Pendekatan Praktik). Jakarta: Rineka Cipta, 2013.

J. R. E. Kaligis and H. Darmodjo, Pendidikan IPA. 1992. 
S. Hafsoh, "Pengembangan Bahan Ajar Berupa Lks Dengan Metode Inkuiri Terbimbing (Guided Inquiry) Pada Pembelajaran Ipa Materi Interaksi Makhluk Hidup Dan Lingkungannya Kelas Vii Semester Genap Di Mts Negeri Kendal," Fakultas Sains Dan Teknologi Universitas Islam Negeri Walisongo Semarang, 2017.

U. Khasanah, "Pengembangan Lembar Kerja Siswa (Lks) Berbasis Inkuiri Terbimbing Berbantuan Media Grafis Pada Mata Pelajaran Matematika Kelas VIII Mts Al-Hikmah Bandar Lampung," Jurusan Pendidikan Matematika Fakultas Tarbiyah Dan Keguruan Institut Agama Islam Negeri Raden Intan Lampung, 2016.

D. Kusumaningrum, "Literasi Lingkungan Dalam Kurikulum 2013 dan Pembelajran IPA di SD," vol. 1, no. 2, pp. 57-64, 2018.

LIPI-UNESCO/ISDR, Kajian Kesiapsiagaan Masyarakat Dalam Mengantisipasi Bencana Gempa Bumi dan Tsunami. Jakarta, 2006. 